\title{
Selvrapportert fysisk aktivitet i norske befolkningsundersøkelser - et metodeproblem
}

\author{
Nanna Kurtze ${ }^{1}$, Kjell Terje Gundersen ${ }^{2}$ og Jostein Holmen ${ }^{1}$ \\ ${ }^{1}$ HUNT forskningssenter, Institutt for samfunnsmedisin, NTNU, Neptunveien 1, 7650 Verdal \\ ${ }^{2}$ Høgskolen i Nord-Trøndelag, Avd. Larerutdanning, Levanger \\ Korrespondanse: Nanna Kurtze, SINTEF Unimed, Postboks 124, Blindern, 0314 Oslo \\ Telefon: 22067438 Telefax: 22067909 E-post: nanna.kurtze@sintef.no
}

\begin{abstract}
SAMMENDRAG
Nasjonalt og internasjonalt mangler fremdeles en "gullstandard" for måling av fysisk aktivitet. Derfor er det viktig å validere spørsmål om fysisk aktivitet for å kunne sammenlikne forskjellige undersøkelser. Denne artikkelen gir en oversikt over ulike metoder som er benyttet for å måle selvrapportert fysisk aktivitet i norske befolkningsundersøkelser, og drøfter konsekvensene av at det er brukt ulike målemetoder. Validitets- og reliabilitetsproblemene drøftes med Helseundersøkelsene i Nord-Trøndelag i 1984-86 (HUNT 1) og i 1995-97 (HUNT 2) som eksempler. Konklusjon: Bruken av ulike metoder for å måle fysisk aktivitet er en betydelig svakhet ved de norske befolkningsundersøkelsene, og det er et tankekors at heller ikke CONOR-spørsmålene, som nå er brukt på ca. 175000 personer, er validert. Det er på høy tid at de epidemiologiske miljøene samler seg for å heve kvaliteten og standardisere metodene før nye befolkningsundersøkelser settes i verk.
\end{abstract}

Kurtze N, Gundersen KT, Holmen J. Self-reported physical activity in population studies - a methodological problem. Nor J Epidemiol 2003; 13 (1): 163-170.

\section{ENGLISH SUMMARY}

There is no standardized method for the assessment of physical activity. Therefore it is important to investigate the validity and comparability of different measures. This report gives an overview over different self-reported methods to assess physical activity in Norwegian cardiovascular and screening data, epidemiological studies, and Health studies (1972-2000), discussing validity and reliability of these instruments. The validity and reliability problems are focusing especially on the questionnaires from physical activity in The Nord-Trøndelag Health Study in 1984-86 (HUNT 1) and in 1995-97 (HUNT 2). Conclusions: The use of different methods to assess physical activity is one of the greatest weaknesses of the Norwegian population studies. It is rather astonishing that the Cohort of Norway (CONOR) questionnaire of physical activity which has been used on a cohort of approximately 175000 respondents has not yet been validated. It is, therefore, important to standardize these methods before follow-up epidemiological research can occur.

\section{INNLEDNING}

Betydningen av fysisk aktivitet $\mathrm{i}$ det forebyggende og helsefremmende arbeid er vel dokumentert (1). Til tross for at det i dag finnes et utall metoder for å måle fysisk aktivitetsnivå direkte eller indirekte, mangler det imidlertid gode målemetoder. Særlig gjelder dette målemetoder som kan nyttes i store befolkningsundersøkelser $(2,3)$. Det eneste alternativet for måling av fysisk aktivitetsnivå i denne typen undersøkelser vil være selvrapportert fysisk aktivitet. Det mangler dessuten en "gullstandard" som andre målemetoder kan valideres mot $(4,5)$, og det mangler epidemiologiske kriterier som målingene kan bygge på. Alt etter hvilke vev, organer og organsystemer en ønsker å studere effekten av fysisk aktivitet på, vil kravene til hyppighet, varighet og intensitet variere (6-8).

For å få et valid mål på det fysiske aktivitetsnivået ved bruk av spørreskjema, er det vanlig å sette som krav at fire dimensjoner skal inkluderes: Hyppighet, dvs. hvor ofte vedkommende driver fysisk aktivitet, varighet, dvs. hvor lenge den varer hver gang, intensitet, dvs. hvor hard aktiviteten er, og regelmessighet, dvs. hvor mye aktiviteten varierer med sesongene, for eksempel mellom sommer og vinterhalvåret (9). I Norge er det i løpet av de siste 25-30 årene gjennomført en rekke store befolkningsundersøkelser der spørsmål om fysisk aktivitet har inngått. Artikkelen her gir en oversikt over de ulike målemetodene som er brukt for å måle selvrapportert fysisk aktivitet i de store befolkningsundersøkelsene gjennomført i Norge i perioden 1972-2000. Konsekvensene for validitet og reliabilitet er drøftet med utgangspunkt i spørsmål fra Helseundersøkelsene i Nord-Trøndelag 1984-86 (HUNT 1) og 1995-97 (HUNT 2) som eksempler.

\section{MAteriale OG Metode}

Artikkelen tar for seg de norske befolkningsundersøkelsene som har omfattet 3000 deltakere eller mer. Tabell 1 viser omlag 20 befolkningsunders $ø$ kelser der 
det også er spurt etter fysisk aktivitet. De fleste er hjerte- og karundersøkelser utført i regi av Statens helseundersøkelser, og de er stort sett bygget over samme lest, men med lokale tilpasninger. I hjerte- og karundersøkelsene, bl.a. i Oslo, Tromsø, Østfold og Aust-Agder, ble de samme spørsmålene om fysisk aktivitet brukt helt fram til 1994. Ved starten av CONOR-prosjektet (Cohort of Norway), der målet er å samle eksponeringsdata fra ca. 200000 personer (10), ble det introdusert nye felles sett av spørsmål. I CONOR inngår blant andre disse fire befolkningsundersøkelsene: Helseundersøkelsen i Tromsø (Tromsø 1994-95), i Nord-Trøndelag (HUNT 2, 1995-97), i Hordaland (HUSK, 1997-99), og Oslo (HUBRO, 2000). Ca. 175000 personer har hittil svart på CONOR-spørsmålene. De er dermed de mest brukte de siste årene. Ved HUNT 1 (1984-86) ble det brukt tre spørsmål om fysisk aktivitet. Hvert spørsmål representerte en dimensjon, dvs. hyppighet, intensitet og varighet. Ved HUNT 2 (1995-97), som var en del av CONOR, ble det brukt to spørsmål som hadde de samme tre dimensjonene som ved HUNT 1, men de var nå innbakt $\mathrm{i}$ hvert av de to spørsmålene om henholdsvis "lett" og "hard" fysisk aktivitet. En forutsetning for å kunne sammenlikne datasettene var at spørsmålene som ble brukt ved HUNT 1 og HUNT 2 uttrykte noen felles mål. Begge spørsmålssettene skilte mellom lett aktivitet, der det ikke ble stilt krav om intensitet ("blir ikke svett/andpusten"), og hard fysisk aktivitet ("blir svett/andpusten"). Det er derfor forsøkt å definere disse to nivåene $\mathrm{i}$ begge datasettene på to måter:

Alternativ 1: Behandling av hvert spørsmål for seg. Variabelen som beskrev hyppighet av fysisk aktivitet $\mathrm{i}$ HUNT 1 ble dikotomisert slik at det ble skilt mellom fysisk inaktive og fysisk aktive (tabell 2). De som rapporterte at de "aldri" drev mosjon ble definert som inaktive, og de andre ble dermed definert fysisk aktive. Ved HUNT 2 ble de som rapporterte "ingen" "lett aktivitet" definert som fysisk inaktive og de andre som fysisk aktive (tabell 1). På denne måten ble det en grov todeling av den selvrapporterte fysiske aktiviteten ved begge undersøkelsene.

Alternativ 2: Konstruksjon av fellesmål. Det ble konstruert et "fysisk aktivitetsnivå" ved HUNT 1 og HUNT 2. For å oppnå dette ble først variabelen hyppighet (HUNT 1) kodet slik som i tabell 2, der 2,5 ganger representerer midtskåren for mosjon 2-3 ganger $\mathrm{i}$ uka. Variabelen varighet ble rekodet slik at kategorien "mindre enn 15 minutter" fikk verdien 0 minutter, kategorien "16-30 minutter" fikk midtskåren 23 minutter, og kategorien "30 minutter - 1 time" fikk midtskåren 45 minutter. "Mer enn 1 time" ble rekodet til 60 minutter. Ved å multiplisere antall ganger (rekodet hyppighetsvariabel, tabell 2) med antall minutter (rekodet varighetsvariabel) fikk vi et mål på hvor mange minutter per uke det ble drevet fysisk aktivitet. Lavest oppnåelige verdi ble 0 (0x0min.) og høyest oppnåelige verdi 420 (7x60min.) (tabell 3). Kategori 1 (tabell 3) ble definert som fysisk inaktive og kategori 2, 3 og 4 ble definert som fysisk aktive. For å bli fysisk aktive ble det definert 60 minutter fysisk aktivitet per uke som et minimum, og det ble stilt krav om belastning slik at respondenten ble andpusten og svett eller tok seg nesten helt ut (kategori 2 og 3, tabell 3) (11).

"Fysisk aktivitetsnivå" i HUNT 2 bygger på de to spørsmålene om fysisk aktivitet (tabell 4), og ble konstruert på tre ulike måter: 1) Definisjon av lett aktivitet (ikke svett/andpusten), 2) Definisjon av hard fysisk aktivitet (svett/andpusten) og 3) Definisjon av en indeks (ved å kombinere variabelen lett og hard fysisk aktivitet). Indeksen ble så delt i tre nivåer, som så igjen ble kategorisert i fysisk inaktive (kategori 1) og fysisk aktive (kategori 2 og 3 ).

\section{RESUlTATER}

Tabell 1 viser den store variasjonen i måten selvrapportert fysisk aktivitet er målt på i de norske befolkningsundersøkelsene (12-19).

Antallet spørsmål som er brukt for å måle fysisk aktivitet $\mathrm{i}$ de ulike undersøkelsene varierer fra ett til tre. Alle hjerte- og karundersøkelsene (1972-1994), Helseundersøkelsen i 1975 (SSB), Levekårsundersøkelsen i 1997 og MMI brukte bare ett enkelt spørsmål, mens CONOR benyttet to spørsmål. Helseundersøkelsen i 1985 (SSB) og Helseundersøkelsen i Hordaland 1992-93 hadde to andre spørsmål. De andre undersøkelsene bruker tre spørsmål for å måle fysisk aktivitet.

Antallet dimensjoner av fysisk aktivitet i de ulike undersøkelsene varierer også. MMI (1985-97) og Samordnet levekårsundersøkelse i 1997 inkluderte bare dimensjonen hyppighet/frekvens, og kontrollerte heller ikke for sesongvariasjoner. Levekårsundersøkelsen i 1998 prøvde å inkludere sesongvariasjoner ved å benytte "vanligvis" i et av spørsmålene, men ikke i de to andre. Øvrige undersøkelser inkluderer de fire dimensjonene ved måling av fysisk aktivitet, men på svært ulike måter.

Sammensetningen av spørsmål og type spørsmål er svært ulik. Flere spørsmål kan hver for seg fange opp dimensjonene hyppighet, varighet og intensitet. Spørsmålene er brukt hver for seg eller i kombinasjon. CONOR har disse tre dimensjonene innbakt $\mathrm{i}$ to spørsmål om henholdsvis lett og hard fysisk aktivitet. Sesongvariasjonen er her forsøkt innebygget ved at deltakerne skal ta "et ukentlig gjennomsnitt for året".

Begrepene som er brukt for å beskrive fysisk aktivitet er også noe forskjellig og har til dels ulikt innhold. Ved de fleste undersøkelsene er begrepet fysisk aktivitet brukt. Andre begrep som brukes er "mosjon", "mosjonerer", "mosjonsidrett", "trening" og "bevegelse og kroppslig anstrengelse" (tabell 1, Hjertekarundersøkelsene 1972-94, Levekårsundersøkelsen 1997, 1998, HUNT 1984-86).

Presisjonsnivået ved slike spørsmål bestemmes bl.a. av typen og antall svarkategorier. Dette varierer $i$ de ulike undersøkelsene fra subjektive kategorier, som 


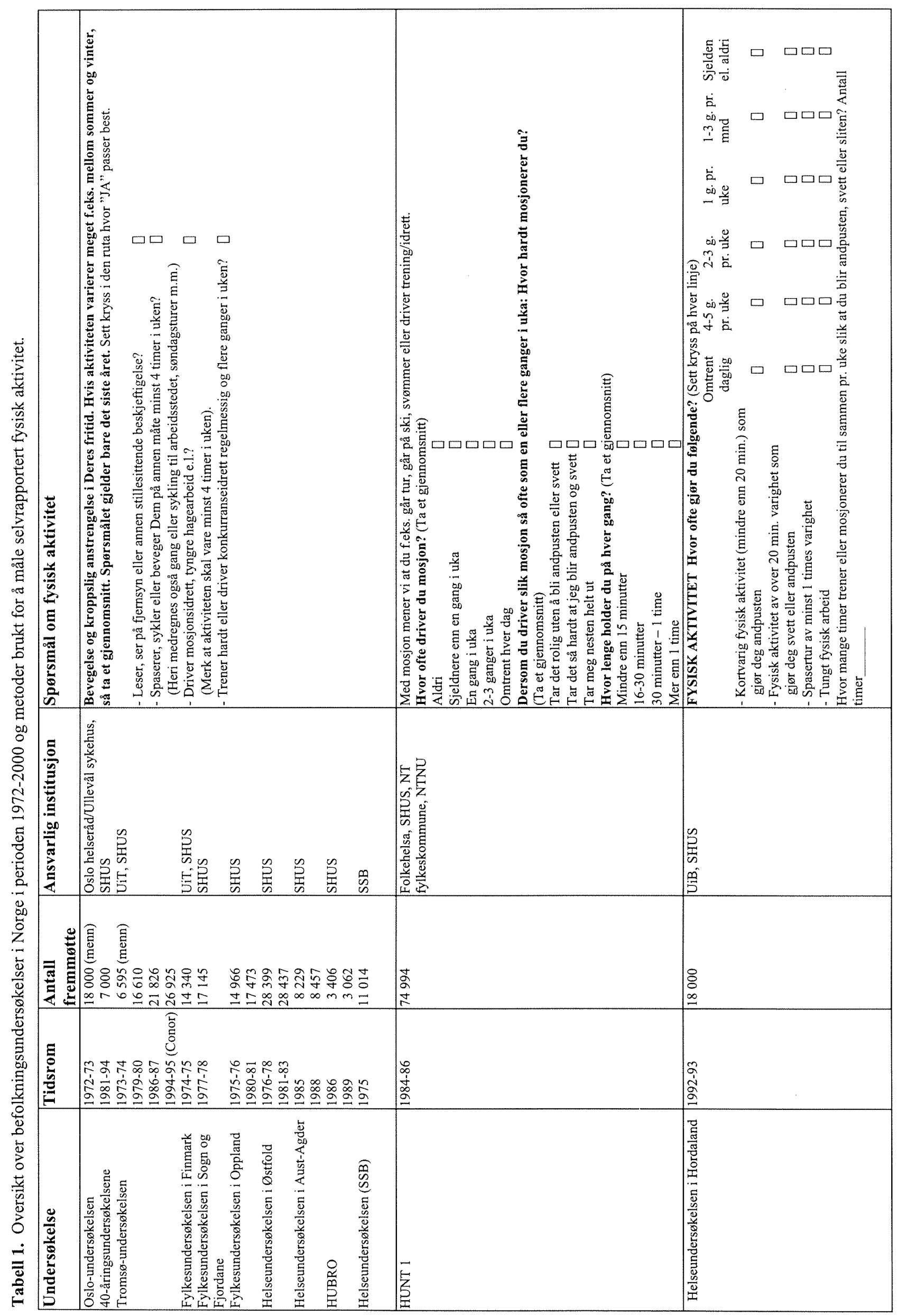




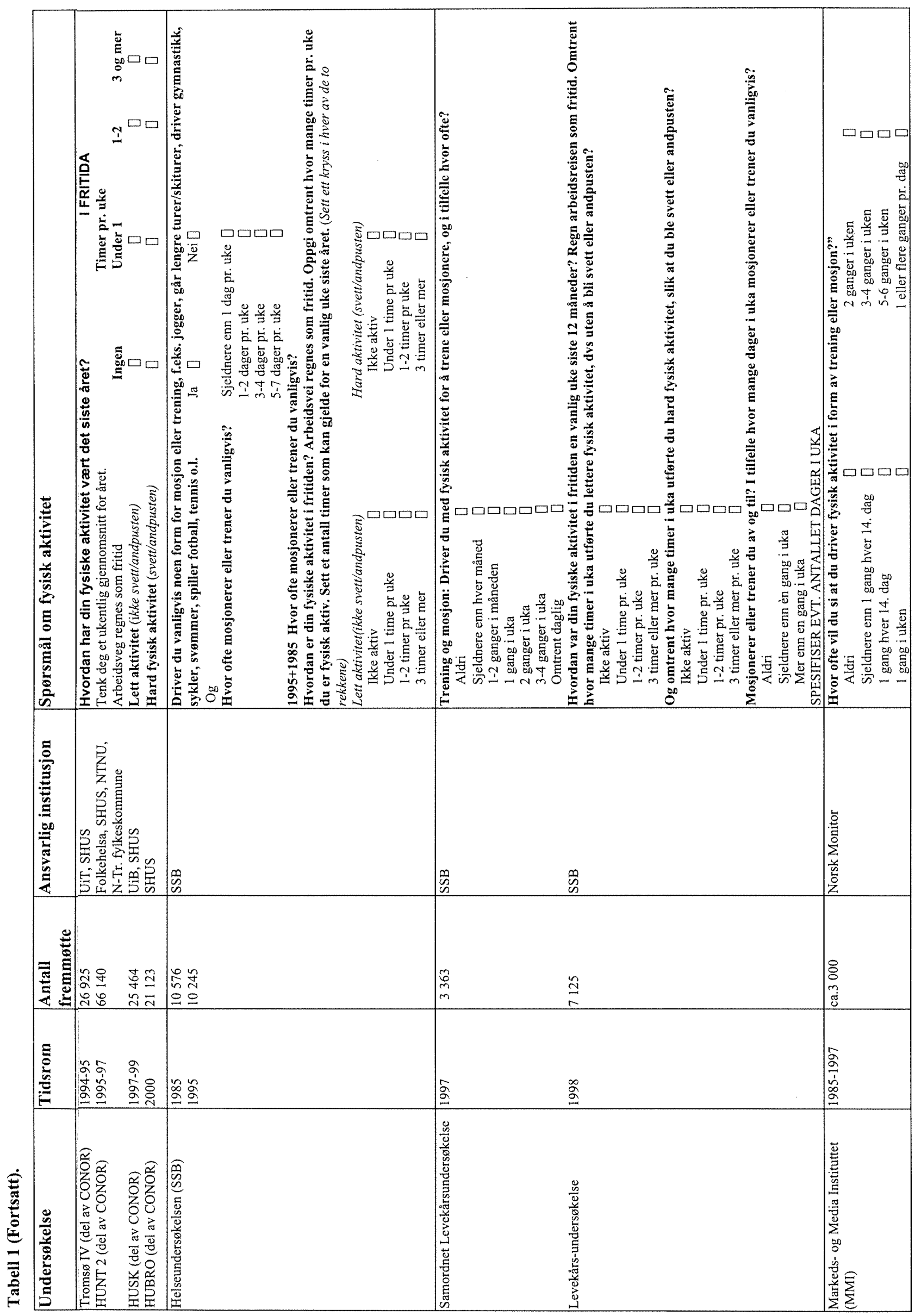


Tabell 2. Kategorisering av hyppighetsvariabelen i HUNT 1: Hvor ofte driver du mosjon?

\begin{tabular}{lccccc}
\hline & \multicolumn{4}{c}{ Antall kategorier } & \\
\cline { 2 - 5 } Tekst & Femdeling & \multicolumn{2}{c}{ Todeling } & Antall ganger \\
\hline Aldri & $\square$ & 1 & 1 & inaktiv & 0 \\
Sjeldnere enn en gang i uka & $\square$ & 2 & 2 & aktiv & 0 \\
En gang i uka & $\square$ & 3 & 2 & aktiv & 1 \\
2-3 ganger i uka & $\square$ & 4 & 2 & aktiv & 2,5 \\
Omtrent hver dag & $\square$ & 5 & 2 & aktiv & 7 \\
\hline
\end{tabular}

Tabell 3. Konstruert fysisk aktivitetsnivå ut fra anslått belastning (i forhold til hjerte/kretsløpsfunksjon) ved HUNT 1.

\begin{tabular}{lll}
\hline Tekst & Minutter & Operasjonalisering \\
\hline $\begin{array}{l}\text { 1. Lite fysisk aktiv } \\
\quad \text { eller }\end{array}$ & $0-420$ & Rolig aktivitet (ikke andpusten/svett) \\
hard fysisk aktivitet & $0-59$ & Andpusten/svett/tar seg nesten helt ut \\
2. Noe fysisk aktiv & $60-119$ & Hard aktivitet (andpusten svett/tar seg nesten helt ut) \\
3. Middels fysisk aktiv & $120-179$ & Hard aktivitet (andpusten svett/tar seg nesten helt ut) \\
4. Meget fysisk aktiv & $180-420$ & Hard aktivitet (andpusten svett/tar seg nesten helt ut) \\
\hline
\end{tabular}

Tabell 4. Konstruert fysisk aktivitetsnivå ut fra anslått belasting ved HUNT 2.

\begin{tabular}{ll}
\hline Tekst & Antall timer per uke \\
\hline 1. Lite fysisk aktiv dersom det er svart 1-4 på variabel lett aktivitet og/eller 1-2 på hard fysisk aktivitet & "ingen", "under 1 time" \\
2. Middels aktiv dersom hard fysisk aktivitet $=3$ & "1-2 timer" per uke \\
3. Meget fysisk aktiv dersom hard fysisk aktivitet $=4$ & "3 timer og mer" \\
\hline
\end{tabular}

for eksempel "tar meg nesten helt ut", til mer objektive kategorier som antall ganger, timer eller minutter. Antall svarkategorier og størrelsen på eventuelle intervaller er også til dels svært forskjellig. Det mest ekstreme var MMI (1985-1997) med åtte svarkategorier for hyppighet ("aldri" til "flere ganger per dag") og Helseundersøkelsen i Hordaland (1992-93) med seks svarkategorier. Hjerte- og karundersøkelsene frem til 1994 hadde bare en avkryssing. Helseundersøkelsen i 1985 (SSB) brukte todelte svarkategorier ("Ja/Nei” på spørsmålet "Driver du vanligvis noen form for mosjon eller trening...").

Ved HUNT 1 rapporterte $13,7 \%$ av mennene og $14,8 \%$ av kvinnene at de aldri mosjonerte, mens ca. en tredel mosjonerte 2-3 ganger i uka eller oftere (tabell 5). Ved HUNT 2, dvs. ca. 11 år senere, rapporterte 9,6\% av mennene og 8,8\% av kvinnene at de ikke drev noen "lett aktivitet" på fritiden (tabell 6). Dersom disse gruppene betraktes som inaktive, tyder det altså på en nedgang $\mathrm{i}$ andelen inaktive $\mathrm{i}$ denne perioden. Ved HUNT 2 rapporterte noen flere kvinner (39,2\%) enn menn $(35,1 \%)$ at de drev lett aktivitet "1-2 timer" per uke. For "3 timer og mer" per uke var forholdet omvendt (36,7\% menn mot 34,9\% kvinner), noe som kan gjenspeile at menn tar lengre treningsøkter og/eller trener oftere enn kvinner (tabell 6). Ved HUNT 2 rapporterte $33,6 \%$ av mennene og $45,9 \%$ av kvinnene at de drev ingen hard aktivitet (tabell 7).

Ved konstruksjon av "fysisk aktivitetsnivå" i HUNT 1 ble $68,0 \%$ menn og 75,9\% kvinner definert som inaktive (11). Til sammenligning ble $67,4 \%$ av mennene og 78,3\% av kvinnene definert som inaktive ved HUNT 2 ut fra et konstruert "fysisk aktivitets- nivå”. Etter denne måten å beregne aktivitetsnivået på, var andelen inaktive altså omtrent uendret i perioden fra HUNT 1 til HUNT 2. Ved oppdeling av aktivitetsnivået i fire kategorier (HUNT 1), rapporterte $8,7 \%$ av mennene at de drev "hard" fysisk aktivitet "2-3 timer" og 8,7\% "3 timer og mer". Tilsvarende tall for kvinner var $6,4 \%$ og $5,8 \%$ (11). Ved HUNT 2 rapporterte $13,9 \%$ av mennene og $6,0 \%$ av kvinnene at de trente "3 timer og mer" (11). Mennene rapporterte altså et høyere aktivitetsnivå i HUNT 2 enn HUNT 1, mens det var omtrent samme andel kvinner. Datamaterialet tillater ikke mer nøyaktige sammenligninger av aktivitetsnivået i HUNT 1 og HUNT 2.

\section{DISKUSJON}

Oversikten i denne studien viser det mangfold av metoder som er brukt for å måle fysisk aktivitet $i$ norske befolkningsundersøkelser de siste 25-30 årene. Det går også frem at kriteriene om at alle fire dimensjonene (hyppighet, varighet, intensitet og regelmessighet) skal være inkludert, er oppfylt bare unntaksvis. Brukt $\mathrm{i}$ analyser innen samme datamaterial kan de ulike metodene likevel til en viss grad uttrykke noe om fysisk aktivitet som kan være nyttig i studier av f.eks. utviklingen av hjerte- og karsykdommer, osteoporose eller andre muskel- og skjelettlidelser. Et mål ved befolkningsstudiene er imidlertid, også å kunne følge utviklingen av risikofaktorer for sykdom over tid. Ikke minst $\mathrm{i}$ dag, med utviklingen av en overvektepidemi, er det av stor betydning å kunne følge utviklingen av den fysiske aktiviteten og inaktiviteten i ulike grupper av befolkningen over tid. 
Tabell 5. "Hvor ofte driver du mosjon?”, Helseundersøkelsen i Nord-Trøndelag 1984-86 (HUNT 1).

\begin{tabular}{|c|c|c|c|c|c|c|}
\hline & \multicolumn{2}{|c|}{ Menn } & \multicolumn{2}{|c|}{ Kvinner } & \multicolumn{2}{|c|}{ Total } \\
\hline & Antall & $\%$ & Antall & $\%$ & Antall & $\%$ \\
\hline Aldri & 4150 & 13,7 & 4654 & 14,8 & 8804 & 14,3 \\
\hline Mindre enn 1 gang per uke & 8410 & 27,8 & 8108 & 25,8 & 16518 & 26,8 \\
\hline 1 gang per uke & 6963 & 23,0 & 7899 & 25,1 & 14862 & 24,1 \\
\hline 2-3 ganger per uke & 6571 & 21,7 & 6796 & 21,6 & 13367 & 21,7 \\
\hline Omtrent hver dag & 4190 & 13,8 & 3991 & 12,7 & 8181 & 13,3 \\
\hline Totalt & 30284 & 100 & 31448 & 100 & 61732 & 100 \\
\hline
\end{tabular}

Oversikten viser dessuten at både antall spørsmål og utformingen av spørsmålene har vært svært ulik. Ved gjennomføringen av epidemiologiske studier må det ofte inngås kompromisser på grunn av plassmangel i spørreskjema. Validiteten i målingene øker ikke nødvendigvis proporsjonalt med antall spørsmål som stilles, men muligheten til å få belyst fenomenet på en bredere og bedre måte øker (20). I mange undersøkelser har hyppighet vært den eneste dimensjonen. Hyppighet kan gi gode indikasjoner på fysisk aktivitetsnivå validert mot objektive målemetoder som maksimalt oksygenopptak, EKG-registreringer, målinger med pedometer, aksellerometer etc. (21-26). Andre studier viser at selvrapportert hard fysisk aktivitet gir bedre reliabilitet og validitet enn aktivitet med moderat intensitet (27). Ainsworth et al. (28) skilte mellom aktive og inaktive bare basert på spørsmål om regelmessig, anstrengende/kraftig aktivitet. Spørsmålet var valid og reliabelt som indikator for tung fysisk aktivitet blant voksne, men ikke i samme grad for lettere og moderat fysisk aktivitet. Trolig vil derfor spørsmålet om hard fysisk aktivitet (CONOR og HUNT 2) gi mer valide data enn spørsmålet om lett aktivitet i disse undersøkelsene (28).

Tabell 6. "I Fritida: Hvordan har din fysiske aktivitet vært det siste året? Tenk deg et ukentlig gjennomsnitt for året, Arbeidsveg regnes som fritid", (Lett aktivitet, dvs. ikke svett/andpusten), Helseundersøkelsen i Nord-Trøndelag 1995-97 (HUNT 2).

\begin{tabular}{lccrrrr}
\hline \multirow{2}{*}{\begin{tabular}{l} 
Lett aktivitet (ikke svett/andpusten) \\
\cline { 2 - 3 } Timer per uke
\end{tabular}} & \multicolumn{2}{c}{ Menn } & & \multicolumn{2}{c}{ Kvinner } \\
\cline { 2 - 3 } Ingen & 2456 & 9,6 & & 2541 & 8,8 \\
Under 1 time & 4712 & 18,5 & & 4966 & 17,2 \\
1-2 timer & 8966 & 35,1 & & 11322 & 39,2 \\
3 timer eller mer & 9374 & 36,7 & & 10073 & 34,9 \\
\hline Totalt & 25508 & 100 & & 28902 & 100 \\
\hline
\end{tabular}

Tabell 7. "I Fritida: Hvordan har din fysiske aktivitet vært det siste året? Tenk deg et ukentlig gjennomsnitt for året, Arbeidsveg regnes som fritid", (Hard aktivitet, dvs. svett/andpusten), Helseundersøkelsen i Nord-Trøndelag 1995-97 (HUNT 2).

\begin{tabular}{lcccccc}
\hline Hard aktivitet (svett/andpusten) & & \multicolumn{2}{c}{ Menn } & & \multicolumn{2}{c}{ Kvinner } \\
\cline { 2 - 3 } \cline { 6 - 7 } Timer per uke & Antall & $\%$ & & Antall & $\%$ \\
\hline Ingen & 7665 & 33,6 & & 10409 & 45,9 \\
Under 1 time & 6067 & 26,6 & & 5694 & 25,1 \\
1-2 timer & 5198 & 22,9 & & 4748 & 20,9 \\
3 timer eller mer & 3877 & 17,0 & & 1827 & 8,1 \\
\hline Totalt & 22845 & 100,1 & & 22678 & 100 \\
\hline
\end{tabular}

Bruken av begreper og operasjonalisering av begrepene er viktig for validiteten til målingene (definisjonsmessig validitet). Hjerte- og karundersøkelsene (1972/73-1994) og HUNT 1 (1984-86) brukte en oppreknende, eksemplifiserende og kjennetegnende operasjonalisering ("leser, ser på fjernsyn eller annen stillesittende beskjeftigelse" og "Med mosjon mener vi at du f.eks. går tur, går på ski”, etc.). Fysisk aktivitet ble altså operasjonalisert i aktiviteter med ulik grad av belastning. For de fleste vil det nok være lettere å forholde seg til bare en dimensjon når en skal svare på et spørsmål. Likevel vil trolig en slik operasjonalisering bedre validiteten.

Begrepet fysisk aktivitet er altomfattende og rommer begreper som mosjon, trening, idretter og konkurranser, men også en rekke andre fysiske aktiviteter som f.eks. bær- og sopplukking (29). Dessuten er begrepet fysisk aktivitet relativt nøytralt, bl.a. ved at det ikke blir stilt krav til intensitet eller varighet. Mosjonsbegrepet er smalere og har innebygget en dimensjon om at det skal gi en viss treningseffekt. Begrepene "lett aktivitet/hard fysisk aktivitet" (CONOR og HUNT 2) er vanskeligere å ta stilling til. Her må respondenten retrospektivt gjenkalle hvilke aktiviteter som utøves, hvor stor belastningen har vært og sette grensen for hva som er lett og hard fysisk aktivitet. Validiteten til målingen vil da bl.a. være sterkt påvirket av hvor denne grensen blir satt.

Presisjonsnivået ved bruk av antall kategorier varierer også i undersøkelsene. Schechtman et al. (24) viste til at det ga god informasjon bare å skille mellom hvem som deltok og ikke deltok i fysisk aktivitet. Et så enkelt mål viste seg å være valid i komplekse epidemiologiske studier der spørreskjema ble brukt.

\section{Sammenlikning mellom HUNT 1 og HUNT 2}

Eksemplet fra HUNT 1 og HUNT 2 illustrerer at de ulike målemetodene medfører betydelige metodeproblemer når en prøver å studere utviklingen av fysisk aktivitet over tid. Den grove inndelingen i fysisk inaktive og fysisk aktive kan tyde på at andelen inaktive har gått noe ned i perioden mellom HUNT 1 og HUNT 2. Men på grunn av de ulike målene, er det ikke mulig å si noe om øvrige endringer i aktivitetsmønsteret. Hellevik (20) peker på at konstruksjon av indekser vil bedre reliabiliteten og dermed validiteten til målingen ved at flere tilfeldige feil reduseres og at flere sider ved fenomenet ivaretas. De tre dimensjo- 
nene i HUNT 1 er forsøkt brukt for å konstruere en indeks, dvs. et fellesmål med produktet av de tre dimensjonene (antall minutter fysisk aktivitet per uke med en gitt belastning), men også ved bruk av en slik indeks møter en på flere problemer:

- Kategoriene for spørsmål om lett og hard fysisk aktivitet i HUNT 2 (1995-97) ble oppgitt i antall timer, mens spørsmål om varighet i HUNT 1 (198486) ble oppgitt i antall minutter.

- Felles grenseverdier ble vanskeliggjort bl.a. fordi time- og minuttverdier ikke var helt samsvarende.

- Sesongvariasjoner i forhold til sommerhalvåret (barmark) og vinterhalvåret (snø og is) var ikke direkte inkludert. Respondentene ble imidlertid bedt om å "ta et gjennomsnitt". Det kan korrigere noe for sesongvariasjoner. Men retrospektive rapporteringer inntil et helt år kan bli unøyaktige.

- HUNT 2 hadde med de samme dimensjonene som HUNT 1, men de var nå innbakt i spørsmålene om lett og hard fysisk aktivitet. Arbeidsveg skulle regnes som fritid, og dette kompliserer sammenlikningen. Respondentene ble bedt om å tenke seg et ukentlig gjennomsnitt for året. Resultatet av en slik indeksberegning blir derfor usikker, og tolkningen må gjøres med stor varsomhet.

\section{Sammenlikning med andre studier}

I MMIs landsrepresentative undersøkelse av befolkningen over 15 år oppga $14 \%$ at de "aldri" trente/mosjonerte. Tilsvarende tall for 1985 var $16 \%$. Her var det en liten nedgang $i$ antall inaktive fra 1985-1997, det samme som HUNT antydet. Målgruppe og spørsmål i MMI-undersøkelsen var imidlertid forskjellig fra HUNT (tabell 1). Breivik \& Vaagbø (30), som analyserte MMI's data, definerte inaktive som de som aldri trente og de som trente/mosjonerte mindre enn en gang per uke. Denne gruppen inaktive var i 1985 42\%, men redusert til 35\% i 1997. Gruppen aktive øker altså fra 1985 til 1997, og andelen inaktive i 1985 samsvarer med andelen inaktive definert i HUNT 1 (41\%). Vaage (31) viste at i SSBs levekårsundersøkelse i 1997 oppga $64 \%$ i alderen 16-79 år at de trente minst èn gang per måned. $28 \%$ trente eller mosjonerte aldri i løpet av et år, mens 7\% trente daglig. Han mente også at det på siste del av 1990-tallet var flere aktive mosjonister blant kvinner enn blant menn. Data for fysisk aktivitetsnivå fra HUNT kan stemme overens med dette. Andelen fysisk aktive kvinner har økt over en 10årsperiode dersom kravet settes til "1-2 timer" per uke. MMI har stilt samme spørsmål om hyppighet i perioden 1985 til 1997 og kan vise til en nedgang i antall inaktive. Men dette er et svært enkelt mål på et relativt begrenset utvalg. Om dette betyr at nordmenn er blitt mer fysisk aktive i denne perioden, er nokså usikkert.
Det er et tankekors at det på tross av at flere hundre tusen nordmenn har svart på spørsmål om fysisk aktivitet de siste 25 årene, er det ikke gjort gode valideringsstudier av målemetoden. Hva de ulike måleinstrumentene faktisk måler av fysisk aktivitet og hvilken effekt det kan ha på muskler, skjelett og hjerte- og karsystem, er derfor usikkert. Det kan f.eks. tenkes at de ulike spørsmålene tolkes ulikt hos menn og kvinner, og kanskje også i ulike aldersgrupper og i ulike sosioøkonomiske grupper. Det er derfor på høy tid at det epidemiologiske miljøet i Norge enes om å lage bedre og validerte måleinstrumenter før nye befolkningsundersøkelser settes ut i livet.

Utfordringene med å finne gode metoder for å måle selvrapportert fysisk aktivitet er like mye et internasjonalt som et norsk problem. Det pågår imidlertid et slikt arbeid, men dette er ikke avsluttet enda. Dette gjelder The International Physical Activity Questionnaire (IPAQ) som er ment å bli hovedinstrumentet $\mathrm{i}$ internasjonale prevalensstudier (http $\backslash$ www.ipaq.ki.se). Det er konstruert to versjoner, et kort spørreskjema som er til for bruk for nasjonale og regionale overvåkingssystemer og et lengre til bruk i forskning. Skjemaene er pretestet og evaluert i forhold til reliabilitet og validitet av European Health Interview Survey (EUROHIS) og European Physical Activity Surveillance System (EUPASS). Til nå er det gjennomført studier i 12 land på seks kontinenter med standardiserte metoder og protokoller, og det er satt et mål å inkludere til sammen 30 land.

\section{KONKLUSJON}

Selv om data om fysisk aktivitet fra de norske befolkningsundersøkelsene har gitt verdifull kunnskap, er den manglende standardiseringen av måleinstrumentene og den manglende valideringen en svakhet, og gjør det bl.a. vanskelig å følge utviklingen av det fysiske aktivitetsnivået $\mathrm{i}$ befolkningen over tid. Eksemplene fra HUNT illustrerer dette. For bl.a. å forstå dagens overvektsepidemi, er det viktig å få standardiserte og validerte måleinstrumenter som kan brukes i befolkningsundersøkelser. Ved fremtidige undersøkelser bør de fire dimensjonene hyppighet, varighet, intensitet og regelmessighet være med i form av enkeltspørsmål. Begrepet fysisk aktivitet er nøytralt og bør brukes entydig. Det må bli enighet om arbeidsvei skal regnes som fysisk aktivitet på fritiden eller ikke. Det bør også gjøres valideringsstudier av noen av de måleinstrumentene som allerede har vært mye brukt, særlig av CONOR-spørsmålene.

Helseundersøkelsen i Nord-Trøndelag (HUNT 1 og 2) er et samarbeid mellom HUNT forskningssenter, det medisinske fakultet, Norges teknisk-naturvitenskapelige universitet (NTNU), Verdal, Nasjonalt Folkehelseinstitutt og Nord-Trøndelag fylkeskommune. 


\section{REFERANSER}

1. Bouchard C, Shephard RJ, Stephens T, editors. Physical Activity, Fitness, and Health International Proceedings and Consensus Statement. Champaign: Human Kinetics Publisher, 1994.

2. Blair SN, Haskell WL, Ho P, Paffenbarger RSJ, Vranizan KM, Farquhar JW, et al. Assessment of habitual physical activity by a seven-day recall in a community survey and controlled experiments. Am J Epidemiol 1985; 122: 794-804.

3. LaPorte RE, Montoye HJ, Caspersen CJ. Assessment of physical activity in epidemiologic research: problems and prospects. Public Health Rep 1985; 100: 131-146.

4. Lamb KL, Brodie DA. The assessment of physical activity by leisure-time physical activity questionnaires. Sports Med 1990; 10: 159-180.

5. Stender M, Doring A, Hense HW, Schlichtherle S, Keil U. Comparison of 2 methods for the assessment of physical activity. Soz Praventivmed 1991; 36: 176-183.

6. Friedenreich CM, Courneya KS, Bryant HE. The lifetime total physical activity questionnaire: development and reliability. Med Sci Sports Exerc 1998; 30: 266-274.

7. Knapik J, Zoltick J, Rottner HC, Phillips J, Bielenda C, Jones B, et al. Relationships between self-reported physical activity and physical fitness in active men. Am J Prev Med 1993; 9: 203-208.

8. Wilbur J, Miller AM, Montgomery A, Chandler P. Women's physical activity patterns: nursing implications. $J$ Obstet Gynecol Neonatal Nurs 1998; 27: 383-392.

9. Strømme SB, Ingjer F. Virkningen av regelmessig fysisk aktivitet på hjertet og kretsløpsystemet. Tidsskr Nor Logeforen 1980; 12B: 747-752.

10. Tverdal A, Graff-Iversen S, red. Statens helseundersøkelser og samarbeidspartnere. Norsk Epidemiologi (temanummer) 1997; 7 (2).

11. Kurtze N, Gundersen KT, Nystad W. "Svett og andpusten jeg?" Fysisk aktivitet blant ungdom og voksne. 132. 2001. Statens institutt for folkehelse, seksjon for epidemiologi i samarbeid med Norges Idrettsforbund og Olympiske Komitè.

12. Helseundersøkelse 1975. Oslo: Statistisk sentralbyrå, 1975.

13. Helseundersøkelse 1985. Oslo-Kongsvinger: Statistisk sentralbyrå, 1985.

14. Håndbok for hjerte-kar undersøkelsen 40-åringsprosjektet. Oslo: Statens helseundersøkelser, 1987.

15. Helseundersøkelsen 1995. Oslo-Kongsvinger: Statistisk sentralbyrå, 1995.

16. Helseundersøkelsene i Østfold 1985 og 1988 og i Aust-Agder 1986 og 1989. Oslo: Statens helseundersøkelser, 1997.

17. Markeds- og Mediainstituttets landsrepresentative undersøkelse av befolkningen over 15 år. Oslo: Norsk Monitor, 1997.

18. Temaroterende levekårsundersøkelse 1998. Oslo-Kongsvinger: Statistisk sentralbyrå, 1998.

19. Samordnet levekårsundersøkelse 1997 - tverrsnittsundersøkelsen. Dokumentasjonsrapport 98/34. Oslo: Statistisk sentralbyrå, 1998.

20. Hellevik O. Forskningsmetode i sosiologi og statsvitenskap. Oslo: Universitetsforlaget, 1993.

21. Gionet NJ, Godin G. Self-reported exercise behavior of employees: a validity study. J Occup Med 1989; 31: 969-973.

22. Philippaerts RM, Westerterp KR, Lefevre J. Doubly labelled water validation of three physical activity questionnaires. Int J Sports Med 1999; 20: 284-289.

23. Richardson MT, Leon AS, Jacobs DRJ, Ainsworth BE, Serfass R. Ability of the Caltrac accelerometer to assess daily physical activity levels. J Cardiopulm Rehabil 1995; 15: 107-113.

24. Schechtman KB, Barzilai B, Rost K, Fisher EB, Jr. Measuring physical activity with a single question. Am J Public Health 1991; 81: 771-773.

25. Siconolfi SF, Lasater TM, Snow RC, Carleton RA. Self-reported physical activity compared with maximal oxygen uptake. Am J Epidemiol 1985; 122: 101-105.

26. Suzuki I, Kawakami N, Shimizu H. Reliability and validity of a questionnaire for assessment of energy expenditure and physical activity in epidemiological studies. J Epidemiol 1998; 8: 152-159.

27. Rauh MJ, Hovell MF, Hofstetter CR, Sallis JF, Gleghorn A. Reliability and validity of self-reported physical activity in Latinos. Int J Epidemiol 1992; 21: 966-971.

28. Ainsworth BE, Jacobs DR, Jr, Leon AS. Validity and reliability of self-reported physical activity status: the Lipid Research Clinics questionnaire. Med Sci Sports Exerc 1993: 25: 92-98.

29. Fasting K. Fysisk aktivitet i fritiden. Et litteraturstudium og en empirisk undersøkelse om hvilke faktorer som er av betydning for utøvelse av fysisk aktivitet i fritiden. Oslo: Norges Idrettshøgskole, 1983.

30. Breivik G, Vaagbø O. Utviklingen i fysisk aktivitet i den norske befolkning 1985-1997. 1-47. 1998. Oslo, Norges Idrettsforbund og Olympiske Komite. Fysisk aktivitet og helse.

31. Vaage OF. Trening og mosjon: Kvinner og menn er like aktive. Samfunnsspeilet 1999; 13: 42-51. 